\title{
Morphological and molecular evidence for Osmundea coelenterata comb. nov. (Ceramiales, Rhodophyta) from the tropical Atlantic Ocean
}

\author{
Evidencias morfológicas y moleculares para Osmundea coelenterata comb. nov. (Ceramiales, Rhodophyta) \\ del Océano Atlántico tropical
}

\author{
Mutue T. Fujii ${ }^{1}$, Abel Sentíes ${ }^{2}$, Abdiel Jover C. ${ }^{3}$, Jhoana Díaz-Larrea ${ }^{2}$ and Arsenio Areces ${ }^{4}$ \\ ${ }^{1}$ Núcleo de Pesquisa em Ficologia, Instituto de Botânica, Av. Miguel Estéfano, 3687 - 04301-902 São Paulo. Brasil \\ ${ }^{2}$ Departamento de Hidrobiología, Universidad Autónoma Metropolitana, Unidad Iztapalapa, Apdo. Postal 55-535, CDMX, 09340. México \\ ${ }^{3}$ Departamento de Biología, Universidad de Oriente, Patricio Lumumba s/n. CP: 90500 Santiago de Cuba. Cuba \\ ${ }^{4}$ Instituto de Oceanología, Primera no. 18406, Rpto. Flores, Playa, Habana. Cuba \\ e-mail: mutue.fujii@pq.cnpq.br
}

Fujii M. T., A. Sentíes, C. A. Jover, J. Díaz-Larrea and A. Areces. 2016. Morphological and molecular evidence for Osmundea coelenterata comb. nov. (Ceramiales, Rhodophyta) from the tropical Atlantic Ocean. Hidrobiológica 26 (2): 203-211.

\begin{abstract}
Background. As part of the monographic studies on the Laurencia complex (Rhodomelaceae, Rhodophyta) from Cuba, detailed taxonomic research was carried out on Laurencia coelenterata, a diminutive species collected in Santiago de Cuba, in the eastern Cuban archipelago. The vegetative and reproductive features of the species clearly belong to the genus Osmundea, a member of the Laurencia complex: two pericentral cells per each vegetative axial segment, tetrasporangia cut off randomly from cortical cells, and filament-type spermatangial branches. Goals. In this study the morphological characteristics previously unknown to Laurencia coelenterata are shown, and in order that their taxonomic position within the Laurencia complex is discussed. Furthermore, the global geographic distribution of the Osmundea species is analysed. Methods. Morphological and molecular analysis of the $r b c \mathrm{~L}$ gene sequences were performed allied with the preparation and interpretation of phylogenetic hypotheses. Results. The new morphological analysis of the paratype specimen (\# 4451) housed in the Puertorriqueño Marine Herbarium showed that Laurencia coelenterata was incorrectly placed in the genus Laurencia. The phylogenetic position of the present species was inferred by the analysis of the chloroplast-encoded $r b c \mathrm{~L}$ gene sequences, and the range of the genetic variation found in this analysis also supports the transfer of Laurencia coelenterata to the genus Osmundea, as 0. coelenterata (D. L. Ballantine et Aponte) M.T. Fujii, Sentíes et Areces. Conclusions. The morphological and molecular approach in algal taxonomy is allowing consolidate the nomenclatural status of the species, and the new combination for Laurencia coelenterata as Osmundea coelenterata is not an exception.
\end{abstract}

Key words: Laurencia sensu lato, Osmundea, rbcL, Santiago de Cuba, taxonomy.

\section{RESUMEN}

Antecedentes. Como parte de los estudios monográficos sobre el complejo Laurencia (Rhodomelaceae, Rhodophyta) en Cuba, se llevó a cabo la recolecta e investigación taxonómica detallada de una pequeña especie Laurencia coelenterata, presente en Santiago de Cuba, región oriental del archipiélago cubano. Los caracteres vegetativos y reproductivos presentes en esta especie y que son exclusivos del género Osmundea (miembro del complejo Laurencia) son: dos células periacentrales por cada segmento axial vegetativo, los tetrasporangios nacen al azar de las células corticales y las ramas espermatangiales son de tipo "filamento". Objetivos. En este trabajo se describen caracteres morfológicos previamente no conocidos para Laurencia coelenterata y se discute su posición taxonómica dentro del complejo Laurencia. Además se analiza la distribución geográfica global de las especies de Osmundea. Métodos. Se realizaron análisis morfológicos y moleculares de secuencias del gen $r b c$ L. Complementándose con la elaboración e interpretación de las hipótesis filogenéticas. Resultados. El análisis morfológico actual del paratipo (\# 4451) resguardado en el Herbario Marino Puertorriqueño mostró que $L$. coelenterata fue ubicado de manera incorrecta dentro del género Laurencia. La posición filogenética de esta especie fue inferida por secuencias del gene cloroplástico $r b c \mathrm{~L}$ y el intervalo de variación genética encontrado, también soporta la transferencia de Laurencia coelenterata al género Osmundea, como 0. coelenterata (D. L. Ballantine et Aponte) M.T. Fujii, Sentíes etAreces. Conclusiones. La aproximación morfológica y molecular en la taxonomia algal esta permitiendo consolidar el status nomenclatural de las especies, este estudio no es la excepción para la nueva combinación de Osmundea coelenterata.

Palabras clave: Laurencia sensu lato, Osmundea, rbcL, Santiago de Cuba, taxonomía. 


\section{INTRODUCTION}

Laurencia coelenterata D. L. Ballantine and Aponte (Ballantine et Aponte, 1995) is a diminutive species, originally collected from the Dry Tortugas, Florida, at $9 \mathrm{~m}$ depth. According to the authors, the name given to it was due to the superficial resemblance of juvenile plants to an anemone. Despite this characteristic, the species is not easily found in the natural environment because of its small thalli.

The taxonomy of the red algal genus Laurencia J. V. Lamouroux sensu lato is extremely complicated because of the large degree of morphological plasticity and worldwide distribution from temperate to tropical oceans. Consequently, the taxonomic position of the species in this group has changed rapidly as new morphological and molecular data are processed. In the roughly two hundred years since the creation of the genus Laurencia (Lamouroux, 1813), many changes have been proposed in what we currently refer to as the Laurencia complex, made up of seven formally proposed genera: Laurencia sensu stricto, Osmundea Stackhouse (Stackhouse, 1809), Chondrophycus (Tokida et Saito) Garbary et J. T. Harper (Garbary \& Harper, 1998), Palisada (Yamada) K. W. Nam (Nam, 2007), Laurenciella Gil-Rodríguez, Sentíes, Díaz-Larrea, Cassano et M. T. Fujii (Cassano et al., 2012), and most recently Coronaphycus Metti, (Metti et al., 2015).

In the Cuban archipelago, the Laurencia complex has 17 species, distributed into 3 genera: Laurencia sensu stricto (11), Palisada (5), and Yuzurua (1 with two varieties) (Suárez et al., 2015).

During the Laurencia complex expedition to the eastern coast of the Cuban archipelago, Laurencia coelenterata was found growing on the consolidated substrata in a biogenic sand beach, with limestone and beds of the seagrass Thallasia testudinum Banks ex König at the bottom. The detailed morphological studies carried out on this material revealed vegetative and reproductive characteristics belonging to the genus $0 s$ mundea, and not to the genus Laurencia (Ballantine \& Aponte, 1995). In this study, previously unknown morphological features of $L$. coelenterata are revealed that justify its transfer to Osmundea. Emendation to the species's original description is provided. The new combination is corroborated by chloroplast-encoded $r b c \mathrm{~L}$ gene-sequence analysis.

\section{MATERIAL AND METHODS}

Study area. Samples were collected at the Cazonal beach, Santiago de Cuba (19०53'39" N and $75^{\circ} 31^{\prime} 8.7$ " W), Cuba. Cazonal is a biogenic sand beach, $60 \mathrm{~cm}$ deep, with isolated limestone and beds of the seagrass Thallasia testudinum at the bottom. The beach is located $52 \mathrm{~km}$ east of the city of Santiago de Cuba.

Morphological study. Transverse and longitudinal hand sections were made with a stainless-steel razor blade and stained with $0.5 \%$ aqueous aniline blue solution, acidified with $1 \mathrm{~N} \mathrm{HCl}$, to highlight the diagnostic morphological features.

The microscopic measurements were obtained using a calibrated ocular micrometer. Photographs were taken with a Panasonic FT3 Lumix digital camera and the photomicrographs were obtained using a Zeiss Axiocan ERC-5S digital camera (Göttingen, Germany) coupled to an Axioskop 2 Zeiss microscope (Göttingen, Germany). The vouchers were deposited at the herbarium of the Instituto de Botânica, at São Paulo, Brazil (SP) and at the phycological collections of the Oriente University, at Santiago de Cuba, Cuba (FCA 191-ah).
Molecular study. Samples for molecular analysis were cleaned, dried, and preserved in silica gel. Total DNA was extracted using a DNeasy Plant Mini Kit (QIAGEN, Valencia, CA, USA), according to the manufacturer's instructions. The $r b c \mathrm{~L}$ gene was amplified in three overlapping fragments with the primer pairs suggested by Freshwater \& Rueness (1994), using the Taq polymerase chain reaction (PCR) Core Kit (QIAGEN). All PCR products were analyzed by electrophoresis in $1 \%$ agarose to confirm product size. The PCR products were purified with the QIAquick Purification Kit (QIAGEN) according to the manufacturer's recommendations. Cycle sequencing was carried out on an ABI PRISM 3100 Genetic Analyzer (Applied Biosystems, Carlsbad, CA, USA), using the BigDye Terminator Cycle Sequencing Reaction Kit (Applied Biosystems). Primers were used for PCR amplification and cycle sequencing. Sequences were analyzed with Sequence Navigator software, version 1.0.1 (Applied Biosystems).

Phylogenetic analyses. Phylogenetic relationships were inferred with PAUP* version 4.0b10 (Swofford 2002) and MrBayes v.3.0 beta 4 (Huelsenbeck \& Ronquist, 2001). Maximum parsimony (MP) trees were constructed by applying the heuristic search option, tree-bisectionreconnection (TBR) branch swapping, with unordered and unweighted characters, and gaps treated as missing data. Modeltest software, version 3.7 (Posada \& Crandall, 1998), was used to find the model of sequence evolution least rejected in each data set by a hierarchical likelihood ratio test. Once the evolution model had determined a Maximum Likelihood (ML), searches were performed by applying the estimated parameters (substitution model, gamma distribution, proportion of invariant sites, and frequencies of the bases). Maximum likelihood analysis was then employed to construct the most likely tree from the data set. Maximum Likelihood and MP branch supports were calculated by nonparametric bootstrapping analysis (Felsenstein, 1985), as implemented in PAUP*.

The general time-reversible model of nucleotide substitution with invariant sites and gamma-distributed rates for the variable sites (GTR $+\mathrm{I}+\mathrm{G}$ ) were used for Bayesian analysis (BI). This model was selected based on an ML ratio test implemented by the software Modeltest, version 3.06 (Posada \& Crandall, 1998), with a significance level of 0.01 . For Bayesian analysis, we ran four chains of Markov Chain Monte Carlo, sampling one tree every 1,000 generations for $4,000,000$ generations, starting with a random tree. A $50 \%$ consensus tree-majority rule (as implemented by PAUP*) was computed after the burn-in point. The range of $r b c \mathrm{~L}$ divergence values within and between species was calculated using uncorrected " $p$ " distances obtained from PAUP*.

\section{RESULTS}

Osmundea coelenterata (D.L. Ballantine et Aponte) M.T. Fujii, Sentíes et Areces comb. nov. (Figs 1-9).

BASIONYM: Laurencia coelenterata D.L. Ballantine et Aponte, 1995, Bot. Mar. 38: 417-418, figs. 1-2).

HOLOTYPE: US (D.L. Ballantine \# 3908)

PARATYPE: Herbario Marino Puertorriqueño \# 4451!

TYPE LOCALITY: Pulaski Shoals, Dry Tortugas, Florida, USA (24041.661" N, 8242.296”W). 

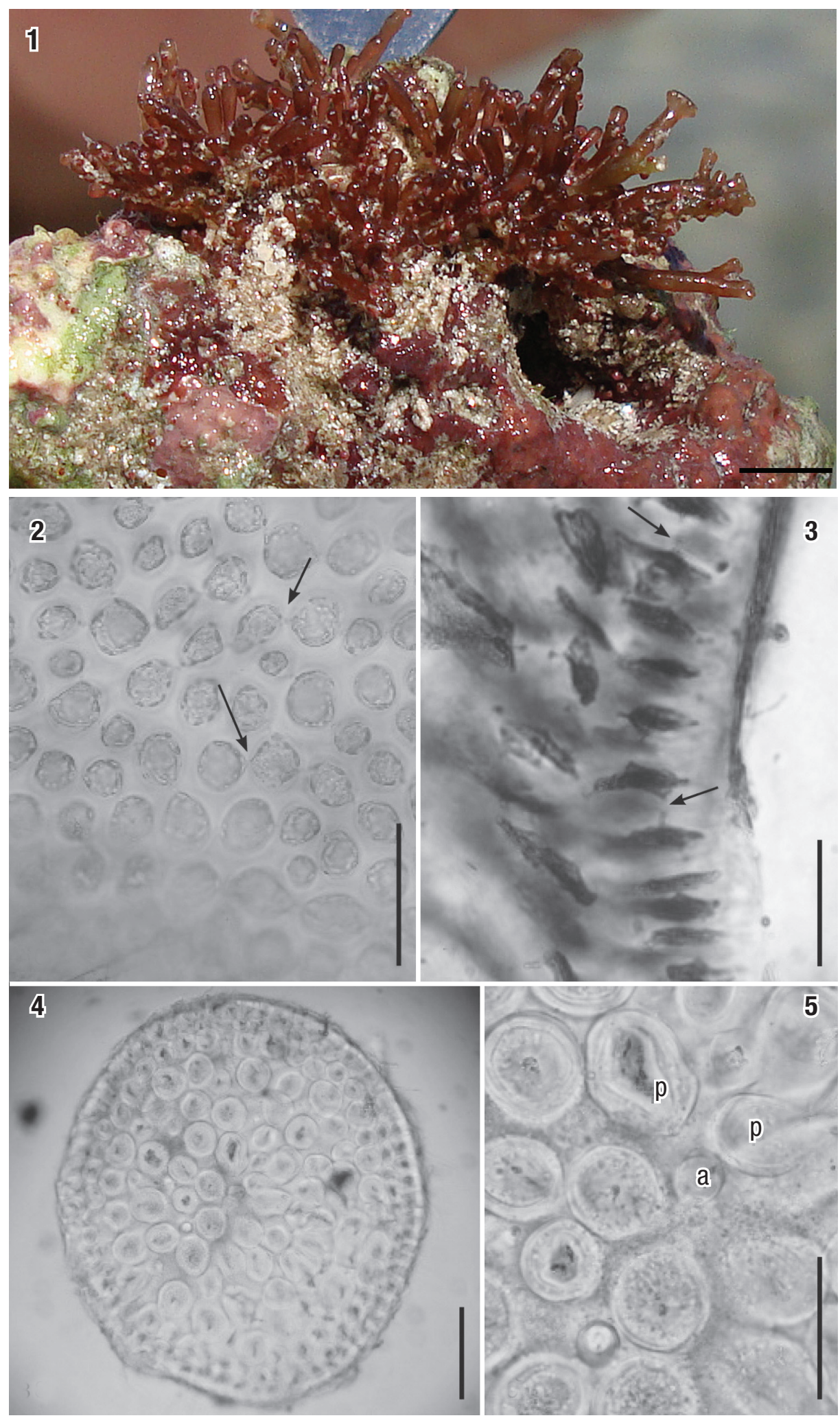

Figures 1-5. Osmundea coelenterata comb. nov. 1 Aspect of a tuft from Cuba on the natural substrate. Scale bar: $2 \mathrm{~mm}$. 2-3) Cortical cells in surface view and in longitudinal section view, respectively. Arrows indicate secondary pit connections. 4) Transverse section of the thallus (note thick-walled medullary cells). 5) Detail of medulla in transverse section, showing an axial cell (a) with two pericentral cells (p). Scale bars $=100 \mu \mathrm{m}$ (Figs 2, 5), $50 \mu \mathrm{m}$ (Fig. 3) and $200 \mu \mathrm{m}$ (Fig. 4). 


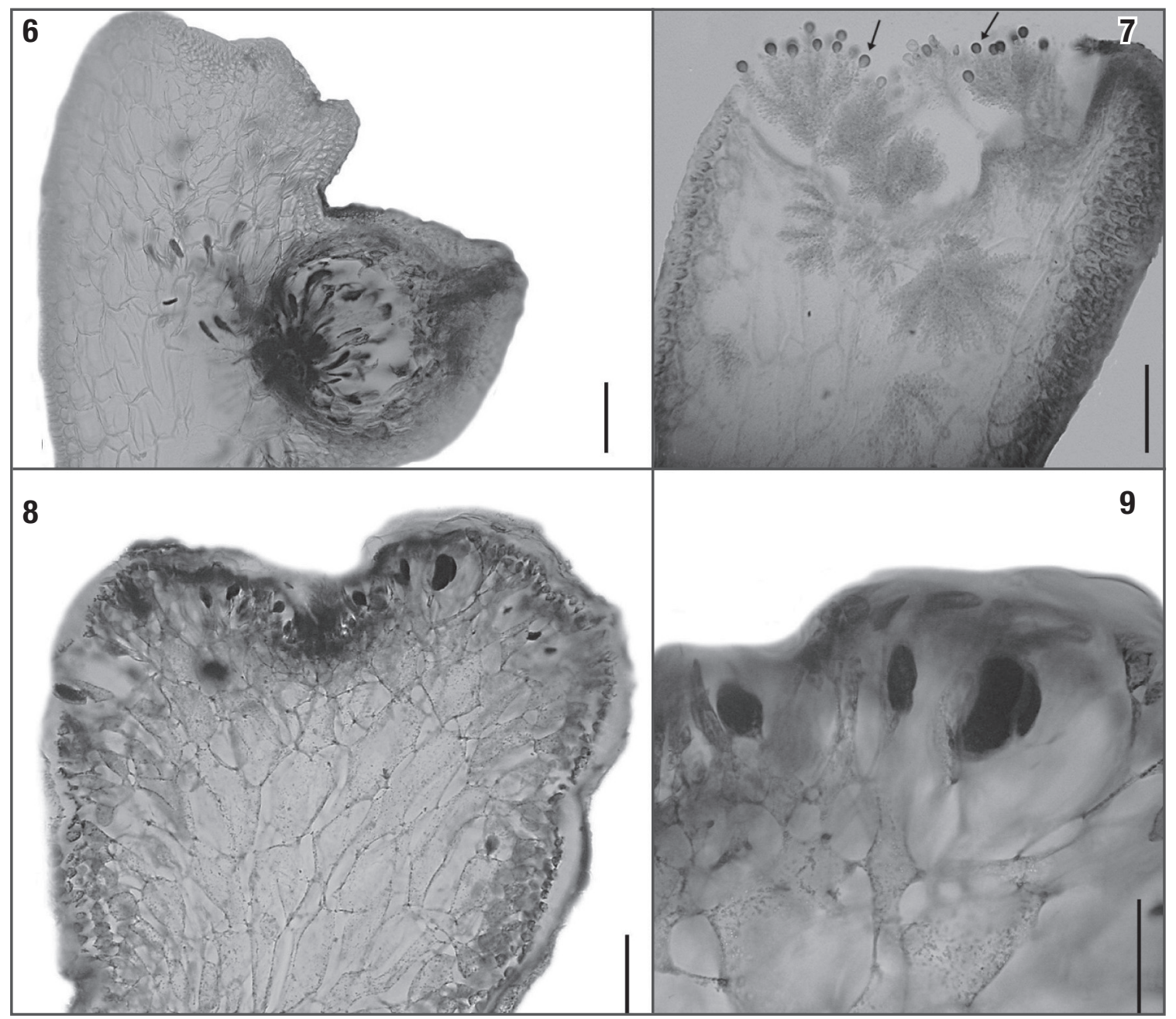

Figures 6-9. Osmundea coelenterata comb. nov. 6) Longitudinal section through a mature cystocarp (note the cystocarp partially immersed in the thallus). 7) Longitudinal section through a cup-shaped spermatangial pit, showing "filament-type" spermatangial branches originated from cortical cells, and terminating in a single vesicular sterile cell (arrows). 8-9) Longitudinal sections through the tetrasporangial branches, with tetrasporangia originated from cortical cells, and showing right angle arrangement in relation to the branch. Scale bars $=100 \mu \mathrm{m}$ (Figs 6, 8), $50 \mu \mathrm{m}$ (Figs 7, 9).

Amended diagnosis: vegetative axial segment with two pericentral cells, whose diameters are slightly smaller than those of the surrounding cells; male gametophytes with 'filament-type' spermatangial branches originated from apical and cortical cells; tetrasporangia are randomly produced from cortical cells at the apex of the branches.

Habit: plants forming tufts, strongly attached to the substrate by a discoid holdfast, rigid, cartilaginous in texture, not adhering to herbarium paper when dried. The thalli are reddish-brown, the axes terete to slightly compressed, claviform, 3-4 mm high and 500-800 $\mu \mathrm{m}$ diameter. The axes are sparsely branched and the branches are produced alternately. Short branchlets are present in the apical portions of some branches and axes, giving the species a very characteristic appearance (Fig. 1).
Vegetative structures: in surface view, cortical cells are rounded, regularly arranged throughout the thalli, 10-25 $\mu \mathrm{m}$ diameter, with secondary pit connections frequently present between the cortical cells (Fig. 2). Corps en cerise absent. In transverse section, thalli with one-two layers of quadratic to slightly radially elongated pigmented cortical cells, not arranged as palisade, 20-35 $\mu \mathrm{m}$ high $\times 20-30 \mu \mathrm{m}$ wide in the middle portions of the main axes (Fig. 3). Medullar region with three or four layers of colorless cells, rounded, (50)90-130 $\mu \mathrm{m}$ diameter, where the pericentral cells are smaller than those in the other layers. Medullary cell walls are extremely thick and can almost completely fill the lumen of the cells. However, lenticular thickenings are absent (Figs 4-5). Each vegetative axial segment cuts off two pericentral cells, rounded, 90-130 $\mu \mathrm{m}$ diameter (Fig. 5). In median longitudinal section through a branchlet, cortical cell walls near apices not projecting beyond the surface. 
Reproductive structures: female gametophytes are characterized by laterally bearing cystocarps partially immersed in the thalli. The cystocarps are pyriform, 350-500 $\mu \mathrm{m}$ diameter, bearing a prominent carpostome. Carpospores are claviform, 40-45 $\mu \mathrm{m}$ high x 10-15 $\mu \mathrm{m}$ wide, and are produced abundantly (Fig. 6). Male gametophytes have filament-type spermatangial branches originating in cortical cells in the cup-shaped spermatangial pit. Spermatangial branches bear spermatangial mother cells that give rise to several elliptical spermatangia, 4-8 $\mu \mathrm{m}$ diameter, each with a single distally located nucleus, and usually terminating in one elliptical vesicular sterile cell, 7-8.5 $\mu \mathrm{m}$ high $\mathrm{x}$ 6.0-6.5 $\mu \mathrm{m}$ wide. (Fig. 7). Tetrasporangia are cut off randomly from the cortical cells at the apex of the branches and have a diameter of 50-80 $\mu \mathrm{m}$, displaying right-angle arrangement in relation to the longitudinal axes. The fertile pericentral cells cut off two presporangial cover cells distally and the tetrasporangia. The post-sporangial cell was not discernible (Figs. 8-9).
Habitat and distribution: The holotype specimens were collected by SCUBA at $9 \mathrm{~m}$ depth at the Dry Tortugas, Florida, USA. In Santiago de Cuba, however, Osmundea coelenterata was found growing on the consolidated substrata in a biogenic sand beach, with isolated limestone and beds of the seagrass Thallasia testudinum at the bottom.

Material examined: CUBA: ID0-161, Cayo Paredon Grande, Archipiélago Jardines del Rey (intertidal), 21.x.1992, Leg. A. Areces (SP 401499). Santiago de Cuba, Playa Cazonal, 12.xi.2008, Leg. A. Jover Capote, female, male, and tetrasporangial specimens (FCA 191-ah).

Additional material examined: Laurencia coelenterata, USA, Dry Tortugas, Pulaski Shoals, 9 m, 17.ix.1991, Leg. David L. Ballantine, (Herbario Marino Puertorriqueño \# 4451 - Paratype) (Figs 10-13).

Molecular analyses. A total of 37 sequences were analyzed including five outgroup taxa, Bostrychia radicans (Montagne) Montagne, Chondria
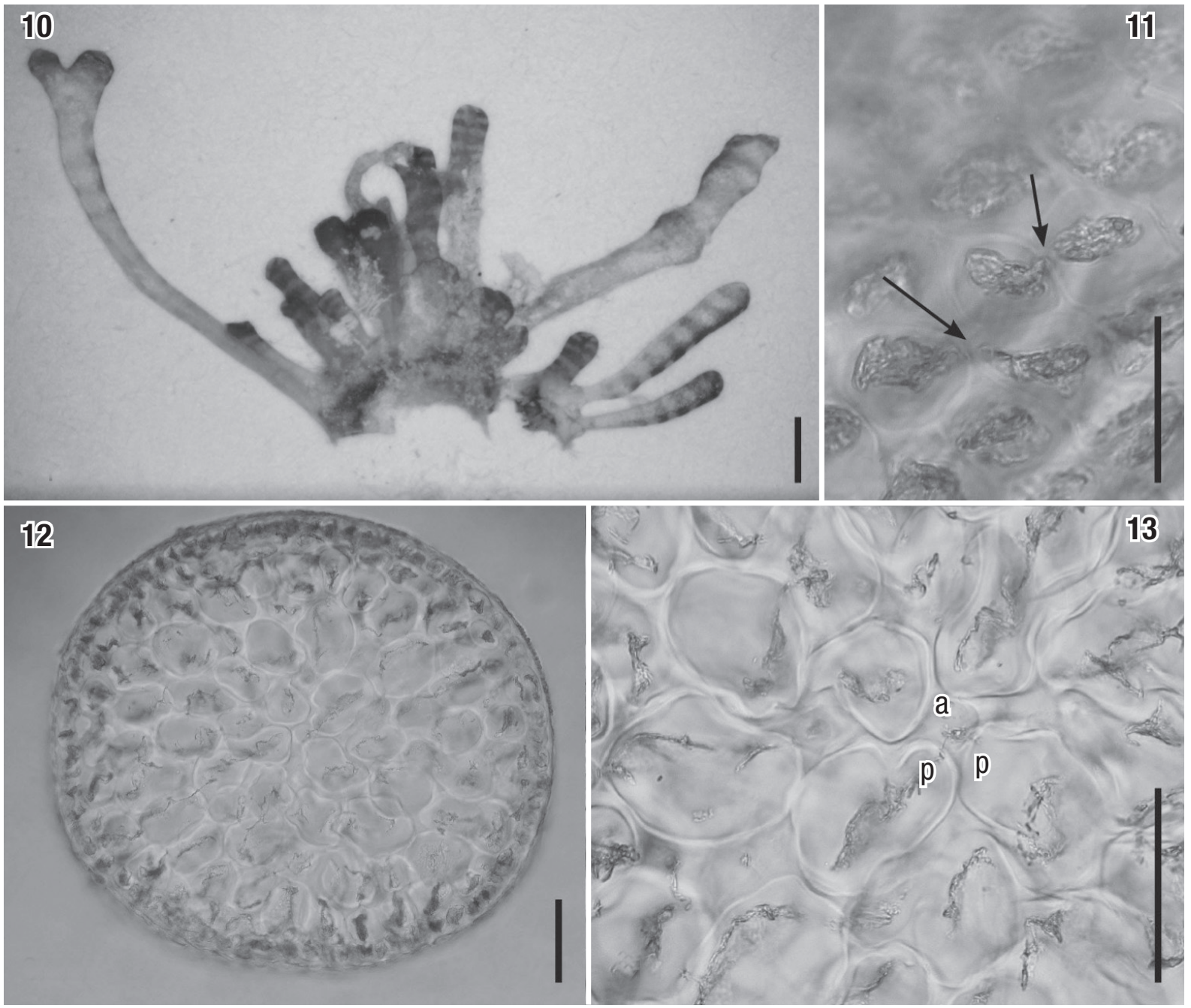

Figures 10-13. Paratype of Laurencia coelenterata (\# 4551). 10) Habit of the plant. 11) Cortical cells in surface view, showing a secondary pit-connection between them (arrows). 12) Transverse section of the thallus. 13) Detail of the upper portion of a branch with an axial cell (a) and two pericentral cells (p). Scale bars: $1 \mathrm{~mm}$ (Fig. 10), $50 \mu \mathrm{m}$ (Figs 11 and 13) and $100 \mu \mathrm{m}$ (Fig. 12). 
collinsiana M. A. Howe, C. dasyphylla (Woodward) C. Agardh, C. californica (Collins) Kylin in the Rhodomelaceae, and Ceramium brevizonatum $\mathrm{H}$. E. Petersen in the Ceramiaceae. Maximum Parsimony, ML and BI topologies were similar. The first 50 nucleotides and the last $40 \mathrm{bp}$ of all $r b c \mathrm{~L}$ sequences were removed, producing a data set of 1377 base pairs, and the rest of the sequences were aligned without ambiguity.
Intergeneric divergence varied from 9.2 to $13.7 \%$ for Laurencia and Osmundea from 8.5 to $12 \%$ for Chondrophycus and Laurencia, from 9 to $11.5 \%$ for Chondrophycus and Osmundea, from 8 to $10 \%$ for Laurenciella and Laurencia, from 8.2 to $10 \%$ for Laurenciella and Palisada, from 10 to $11 \%$ for Laurenciella and Chondrophycus, from 10 to $13 \%$ for Laurenciella and Osmundea, from 9.8 to $10.2 \%$ Laurenciella and $Y u-$

Bostrychia radicans USA (AF259497)

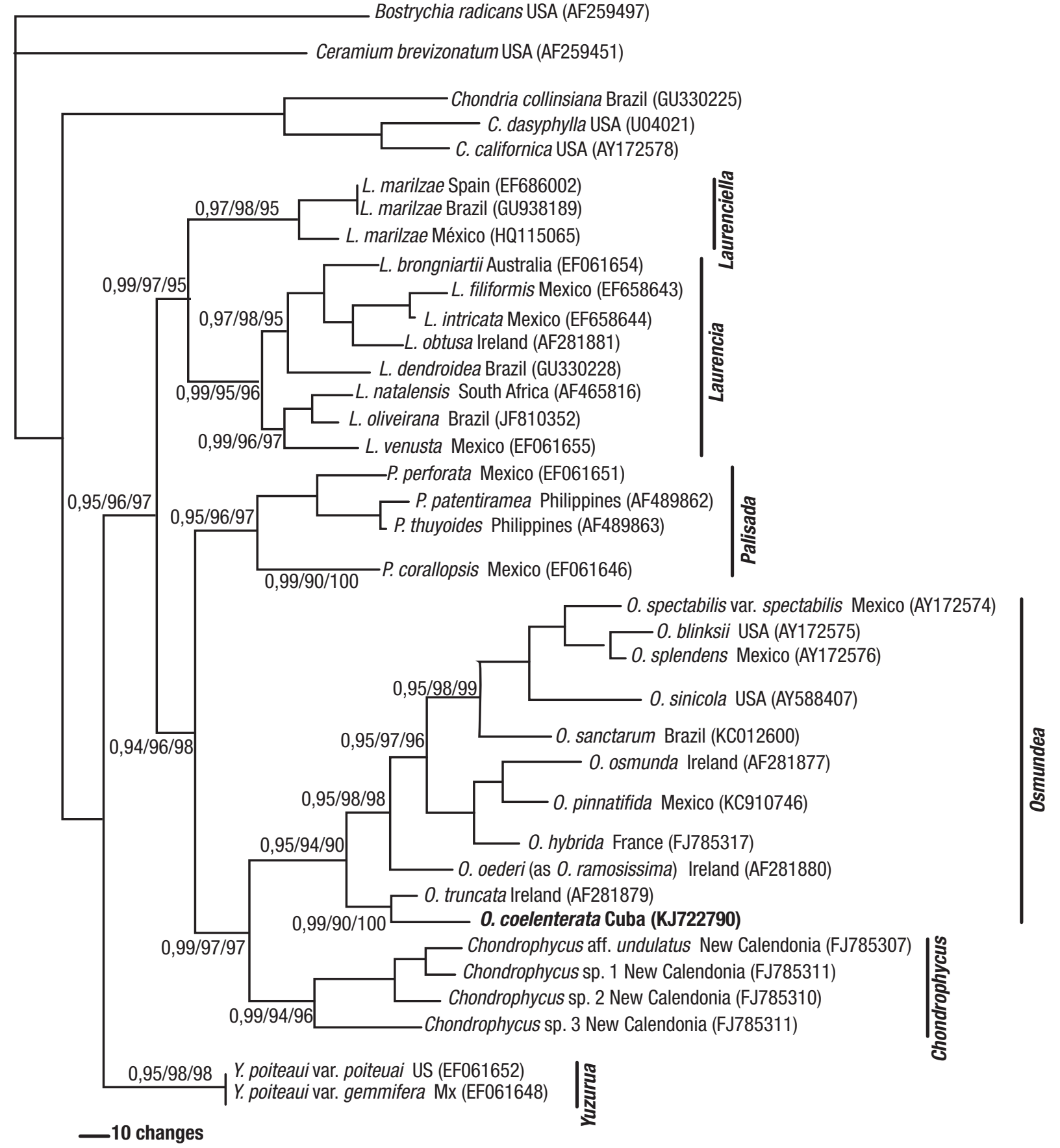

Figure 14. Phylogenetic relationships in the Laurencia complex based on Bayesian analysis of $r b c L$ DNA sequences. Bayesian posterior probability/MP bootstrap/and ML bootstrap values are indicated at the nodes. Taxa marked in bold indicate newly determined sequence. 
zurua, from 7 to $10.5 \%$ for Laurencia and Palisada, from 8.5 to $10 \%$ for Laurencia and Yuzurua, from 8 to $9.2 \%$ for Palisada and Chondrophycus, from 8.5 to $12.5 \%$ for Palisada and Osmundea, from 8 to $10.5 \%$ for Palisada and Yuzurua, from 9.5 to $10.8 \%$ for Chondrophycus and Yuzurua, and from 10.5 to $11.9 \%$ for Osmundea and Yuzurua.

Interspecific divergence obtained for the species of Laurencia varied from 1 to $6 \%$, from 1.3 to $6 \%$ for Palisada, from 1.8 to $7 \%$ for Osmundea, from 1.3 to $1.5 \%$ for Laurenciella, $0.5 \%$ for Yuzurua, and from 1.6 to $6 \%$ for those of Chondrophycus.

Finally, the divergence of the Cuban specimen from other Osmundea species was $3.0-8.5 \%$.

The topology of the majority rule Bayesian tree is shown in Figure 14. The data set consisted of 907 constant characters, 170 parsimony informative sites, and 300 parsimony non-informative sites.

The analyses show a monophyletic Laurencia complex with high bootstrap support in relation to the members of the outgroups. The Laurencia complex separated into six clades with high bootstrap support, corresponding to the following genera: Laurencia, Chondrophycus, Osmundea, Palisada, Laurencia, and Laurenciella.

The monophyletic clade that corresponded to the genus Osmundea included eleven species. Within the Osmundea assemblage, the Cuban specimen formed a well-supported clade with 0. truncata (Kützing) K.W.Nam et Maggs from Ireland.

\section{DISCUSSION}

The Cuban specimens formed a well-supported clade with other species of Osmundea corroborating the morphological data. The divergence of the Cuban specimen from other Osmundea species was high, which confirms that it constitutes an authentic taxonomic entity. The intergeneric and interspecific divergence values obtained in the present work are similar to those reported by other authors for the Laurencia complex (Mclvor et al., 2002; Cassano et al., 2012a,b; Machín-Sanchez et al., 2014; Metti et al., 2015).

The genera Laurencia and Osmundea are clearly distinguished genetically as well as morphologically. Some features, such as the presence of the secondary pit connections between cortical cells and the presence/absence of lenticular thickening are shared by both genera, but the majority of diagnostic morphological features are distinct, such as four pericentral cells per vegetative segment in Laurencia against two in Osmundea; the origin of spermatangia and tetrasporangia is random from cortical cells in Osmundea, whereas in Laurencia they are from a particular fertile pericentral cell.

The tetrasporangial arrangement in superficial view of the branches is parallel in Laurencia, whereas it can be parallel or right-angled in Osmundea.

Ballantine and Aponte (1995) had already noticed that L. coelenterata does not conform to Saito's (1967) concept of the subgenera Laurencia and Chondrophycus, since the species possesses tetrasporangia with a right-angle arrangement (a character of the subgenus Chondrophycus), and secondary pit connections between cortical cells (a character of the subgenus Laurencia). Currently, we know that the right-angle arrangement of tetrasporangia is shared mainly by the species of Chondrophycus, Palisada, and Yuzurua, and pit connections between adjacent cortical cells could be present in all members of the Laurencia complex (Nam 2006, Cassano et al. 2012, Metti et al. 2015).

Osmundea truncata from Ireland is the closest species to this species, although their gross morphology is completely distinct. The thallus in 0 . truncata is up to $5 \mathrm{~cm}$ high, slightly or strongly compressed and abundantly branched (Machín-Sanchéz et al., 2012), whereas in 0 . coelenterata it is smaller (3-4 $\mathrm{mm})$, terete, and branching is rare. In relation to the anatomical comparison, Osmundea truncata and 0 . coelenterata have in common the presence of longitudinally arranged secondary pit connections between adjacent cortical cells and cupshaped spermatangial pit. Lenticular thickenings are present in the former but absent in the latter. Furthermore, the genetic divergence between these species is $1.5 \%$, clearly representing two distinct species of Osmundea.

The geographic distribution of the Osmundea species was analyzed based on dataset presented by Guiry and Guiry (2015). In this database, there are 24 species (and infraspecific) names, of which 20 have been flagged as currently accepted taxonomically. Eight species (40\%) of these occur exclusively in the North American Pacific: O. blinksii (Hollenberg et I. A. Abbott) K. W. Nam, O. crispa (Hollenberg) K. W. Nam, 0. estebaniana (Setchell \& N. L. Gardner) J.N. Norris, O. multibulba (E.Y. Dawson, Neushul et Wildman) K. W. Nam, 0. purepecha Sentíes, Mendoza-González et Mateo-Cid, 0. spectabilis (Postels et Ruprecht) K. W. Nam, and O. splendens (Hollenberg) K. W. Nam.

Osmundea lata (M. Howe etW.R. Taylor) Yoneshigue-Valentin, M. T. Fujii et Gurgel and 0. sanctarum M. T. Fujii et Rocha-Jorge occur only in Brazil and they have restricted and timely distribution in subtidal conditions, under the influence of cold waters of the South Atlantic Central Waters (Howe \& Taylor, 1931; Yoneshigue-Valentin et al., 1995, 2003; Rocha-Jorge et al., 2013).

The Northern hemisphere of the Atlantic Ocean, including the Mediterranean, Adriatic Sea, and Macaronesia houses $50 \%$ of the Osmudea species known to date: 0 . hybrida (A. P. de Candolle) K. W. Nam, 0. maggsiana Serio, Cormaci et G. Furnari, 0. oederi (Gunnerus) G. Furnari, 0. osmunda (S. G. Gmelin) K. W. Nam and Maggs, O. pedicularioides (Børgesen) G. Furnari, Serio et Cormaci, 0. pelagiensis G. Furnari, 0. pelagosae (Schiffner) K. W. Nam, 0. pinnatifida (Hudson) Stackhouse, 0. truncata (Kützing) K. W. Nam et Maggs, and 0 . verlaquei G. Furnari (Gury \& Gury 2015). Except Osmundea maggsiana and 0. pelagiensis that are reported only from the Mediterranean and/or Adriatic Sea (Cormaci et al., 1994; Serio et al., 2008), all others are widely distributed in the Northern Atlantic 0cean and beyond but have never occurred in the North American Pacific.

Osmundea pinnatifida is the most widely distributed species in the northern hemisphere of the Atlantic Ocean and also in the Indian and Pacific Oceans (Guiry \& Gury, 2015), characterizing the Hommersand's late Tethyan distribution pattern, according to Mclvor et al. (2002), c0rroborated by Furnari et al. (2004). The reference to this species in Brazil was never confirmed nor was 0. hybrida (Fujii et al., 2011). 
The geographic distribution pattern found for the species of Osmundea suggests their affinity to temperate and warm temperate conditions. Therefore, this is the first report of Osmundea in the Caribbean, occurring in a typical tropical environment. This fact indicates that further studies are needed in the Caribbean region and in the Western Atlantic.

\section{ACKNOWLEDGEMENTS}

This work was partially supported by research grants from the ConseIho Nacional de Desenvolvimento Científico e Tecnológico (CNPq-Proc. 484647/2012-1) and the "Fundação de Amparo à Pesquisa de São PauIo" (FAPESP-Proc. 2012/18775-6). M.T.F. thanks CNPq for a Productivity Fellowship (Proc. 303915/2013-7). A.S. thanks both the UAMI, Consejo de la Div. C.B.S., (Sesión 15.14-131014), and the Secretaría de Educación Pública-PROMEP (UAMI-CA-117). We are very grateful to Dr. David L. Ballantine for sending us the paratype material cited in this study, to Dr. Michel J. Wynne for reading the manuscript and his valuable suggestions for improvement, and to Dr. Liliana María Gómez Luna for her inestimable logistic support.

\section{REFERENCES}

Ballantine, D. L. \& N. E. Aponte. 1995. Laurencia coelenterata (Rhodomelaceae, Rhodophyta), a new diminutive species from the Dry Tortugas, Florida. Botanica Marina 38: 417-421. D0I: 10.1515/ botm.1995.38.1-6.417

Cassano, V., Y. Metti, A. J. K. Millar, M. C. Gil-Rodriguez, A. Senties, J. DiazLarrea, M. C. OlivelRA \& M. T. FuJll. 2012a. Redefining the taxonomic status of Laurencia dendroidea (Ceramiales, Rhodophyta) from Brazil and the Canary Islands. European Journal of Phycology 47: 67-81. DOI: 10.1080/09670262.2011.647334

Cassano, V., M. C. Oliveira, M. C. Gil-Rodriguez, A. Sentíes, J. Diaz-Larrea \& M. T. FuJl. 2012b. Molecular support for the stablishment of the new genus Laurenciella within the Laurencia complex (ceramiales, Rhodophyta). Botanica Marina 55: 349-357. D0l: 10.1515/bot2012-0133,

Cormaci, M., G. Furnari \& D. Serio. 1994. Two new species of Laurencia (Ceramiales, Rhodophyta) from the Mediterranean Sea: Laurencia pelagiensis sp. nov. and Laurencia verlaquei sp. nov. Japanese Journal of Phycology 42: 365-375.

Felsenstein, J. 1985. Confidence limits on phylogenies: an approach using the bootstrap. Evolution 39: 783-791. DOI: 10.2307/2408678

Freshwater, D. W. \& J. Rueness. 1994. Phylogenetic relationships of some European Gelidium (Gelidiales, Rhodophyta) species based on $r b c \mathrm{~L}$ nucleotide sequence analysis. Phycologia 33: 187-194. DOI: 10.2216/i0031-8884-33-3-187.1

Fuji, M. T., V. Cassano, E. M. Stein \& L. R. Carvalho. 2011. Overview of the taxonomy and of the major secondary metabolites and their biological activities related to human health of the Laurencia complex (Ceramiales, Rhodophyta) from Brazil. Brazilian Journal of Pharmacognosy 21: 268-282. DOI: 10.1590/S0102-695X2011005000064
Furnari, G., D. Serio \& M. Cormaci. 2004. Revision of Laurencia pedicularioides (Ceramiales, Rhodophyta). Taxon 53: 453-460. D0I: $10.2307 / 4135621$

Garbary, D. J. \& J. T. Harper. 1998. A phylogenetic analysis of the Laurencia complex (Rhodomelaceae) of the red algae. Cryptogamie Algologie 19: 185-200.

GuIRY, M. D. \& G. M. GuIRy. 2015. AlgaeBase. World-wide electronic publication, National University of Ireland, Galway. http://www.algaebase.org; searched on 09 0ctober 2015.

Howe, M. A. \& W. R. TAYLoR. 1931. Notes on new or Little-known marine algae from Brazil. Brittonia 1: 7-33. DOI: 10.2307/2804654

Huelsenbeck, J. P. \& F. R. Ronquist. 2001. MrBayes: Bayesian inference of phylogeny. Biometrics 17: 754-755. D0l: 10.1093/bioinformatics/17.8.754

Lamouroux, J. V. F. 1813. Essai sur les genres de la famille des thalassiophytes non articulées. Annales du Muséum d'Histoire Naturelle, Paris 20: 21-47, 115-139, 267-293, pl. 713.

Machín-Sánchez, M., J. Díaz-Larrea, M. T. Fujil, A. Sentíes, V. Cassano \& M. C. GIL-RodRiGUEZ. 2012. Morphological and molecular evidences within Osmundea (Ceramiales, Rhodophyta) from Canary Islands, Eastern Atlantic Ocean. African Journal of Marine Science 34: 27-42. D0I: 10.2989/1814232X.2012.673269

Machín-Sánchez, M., L. Le-Gall, A.I. Neto, F. Rousseau, V. Cassano, A. Sentíes, M. T. Fujil, J. Díaz-Larrea, W. F. Prud'Homme Van Reine, C. Bonillo \& M. C. GIL-Rodríguez. 2014. A combined barcode and morphological approach to the systematics and biogeography of $L$. pyramidalis and Laurenciella marilzae (Rhodophyta). European Journal of Phycology 49 (1): 115-127. DOI: 10.1080/09670262.2014.893017

Martin-Lescanne, J., F. Rousseau, B. De Reviers, C. Payri, A. Couloux, C. Cruaud \& L. Le Gall. 2010. Phylogenetic analyses of the Laurencia complex (Rhodomelaceae, Ceramiales) support recognition of five genera: Chondrophycus, Laurencia, Osmundea, Palisada and Yuzurua stat. nov. European Journal of Phycology 45: 51-61. D0l: $10.1080 / 09670260903314292$

Mclvor, L., C. A. Maggs, M. D. Guiry \& M. H. Hommersand. 2002. Phylogenetic analysis of the geographically disjunct genus Osmundea Stackhouse (Rhodomelaceae, Rhodophyta). Constancea 83: 1-11.

Metti, Y., A. J. K. Millar \& P. Steinberg. 2015. A new molecular phylogeny of the Laurencia complex (Rhodophyta, Rhodomelaceae) and a review of key morphological characters result in a new genus: Coronaphycus, and a description of $C$. novus. Journal of Phycology 51 (5): 929-942. DOl: 10.1111/jpy.12333

NAm, K. W. 2006. Phylogenetic re-evaluation of the Laurencia complex (Rhodophyta) with a description of $L$. succulenta sp. nov. from Korea. Journal of Applied Phycology 18: 679-697. D0l: 10.1007/ s10811-006-9073-3 
NAM, K. W. 2007. Validation of the generic name Palisada (Rhodomelaceae, Rhodophyta). Algae 22: 53-55. D0I: 10.4490/ALGAE.2007.22.2.053

Posada, D. \& K. A. Crandall. 1998. Modeltest: testing the model of DNA substitution. Bioinformatics 14: 817-818. D0I: 10.1093/bioinformatics/14.9.817

Rocha-Jorge, R., V. Cassano, M. B. Barros-Barreto, J. Díaz-Larrea, A. Sentíes, M. C. GIL-Rodríguez \& M. T. FuJll. 2013. Osmundea sanctarum sp. nov. (Ceramiales, Rhodophyta) from the southwestern Atlantic Ocean. Phytotaxa 100: 41-56. D0I: 10.11646/phytotaxa.100.1.5.

Serio, D., A. Petrocelli, M. Cormaci, E. Cecere \& G. Furnari. 2008. First record of Osmundea oederi (Gunnerus) G. Furnari comb. nov. (Rhodomelaceae, Rhodophyta) from the Mediterranean Sea. Cryptogamie Algologie 29: 119-127.

StACKHOUSE, J. 1809. Tentamen marino-cryptogamicum, ordinem novum in genera et species distributum in Classe XXIVta Linnaei sistens. Mémoires de la Société Imperiale des Naturalistes de Moscou 2: 50 97.
Suárez, A. M., B. Martínez-Daranas \& Y. Alfonso. 2015. Macroalgas marinas de Cuba. Editorial UH, La Habana. 266 p.

SwofFoRd, D. L. 2002. PAUP. Phylogenetic analysis using parsimony ( ${ }^{*}$ and other methods). Version 4. Sinauer Associates, Sunderland, MA.

Yoneshigue-Valentin, Y., G. J. P. Mitchell \& C. F. D. Gurgel. 1995. Quelques observations préliminaires sur les macroalgues de la plateforme continentale du sud-est brésilien. Acta Botanica Gallica 142: 161165. DOI: $10.1080 / 12538078.1995 .10515704$

Yoneshigue-Valentin, Y., M. T. FuJII \& C. F. D. Gurgel. 2003. Osmundea lata (M. Howe \& W.R. Taylor) comb. nov. (Ceramiales, Rhodophyta) from the Brazilian south-eastern continental shelf. Phycologia 42: 301307. DOI: 10.2216/i0031-8884-42-3-301.1.

Recibido: 12 de marzo de 2015.

Aceptado: 25 de noviembre de 2015. 